\title{
Pandangan Yuridis Sosiologis Fenomena Street Justice Di Dalam Kehidupan Bermasyarakat
}

\author{
Fuadi Isnawan \\ Fakultas Hukum Universitas Islam Indonesia \\ Jalan Tamansiswa No. 158, Yogyakarta \\ +62 899-9519-678/ fuadi.isnawan@gmail.com
}

\begin{abstract}
The law in people's lives serves as a safeguard in living life. The law is present as a guardian of society. However, in fact, the law often found unimplemented. This fact will effect on providing security for the community. The Powerless of the law would lead to what so called street justice or court justice. The long way to get legal procedure grows the society's anger and leads them to take down the punishment by them self. The phenomenon of street justice influenced by several factors, such as the lack of law awareness and its legal compliance. In this paper, we will use empirical research with the perspective of legal sociology.
\end{abstract}

Keywords: Juridical Sociological View; Street Justice Phenomenon; Community Life

\begin{abstract}
Abstrak
Hukum di dalam kehidupan masyarakat berfungsi sebagai pemberi rasa aman dalam menjalani kehidupan. Hukum hadir sebagai pengawal masyarakat. Akan tetapi, sering ditemui hukum kurang bekerja dengan maksimal. Hal tersebut akan berdampak kepada ketidakberdayaan hukum dalam memberi rasa aman bagi masyarakat. Ketidakberdayaan hukum inilah yang akan menyebabkan terjadinya tindakan Street Justice atau pengadilan jalanan. Masyarakat menganggap prosedur hukum terlalu lama, sehingga tercipta suatu keadaaan yang membuat mereka geram dan ingin menghukum pelaku tersebut dengan cara mereka sendiri. Fenomena Street Justice dapat dipengaruhi oleh beberapa faktor yaitu, kesadaran berikut kepatuhan hukumnya. Kesadaran dan kepatuhan hukum tersebut dipengaruhi oleh beberapa factor yang ada di dalam masyarakat. Dalam tulisan ini, akan digunakan penelitian secara empris berperspektif sosiologi hukum.
\end{abstract}

Kata Kunci: Pandangan Yuridis Sosiologis; Fenomena Street Justice; Kehidupan Bermasyarakat

\section{A. PENDAHULUAN}

Hukum diperlukan untuk mengatur kehidupan antar individu dalam sebuah masyarakat, karena tanpa hukum, kehidupan masyarakat akan kacau balau tanpa aturan. Hal tersebut akan ada hubungan yang baik apabila masyarakat menaati 
hukum yang berlaku, sehingga keberadaan hukum menimbulkan suatu keteraturan dan dapat berlaku efektif.

Meningkatnya kejahatan di mana-mana menjadikan masyarakat yang merasa dirugikan memperjuangkan haknya masing-masing. Salah satu cara masyarakat untuk memperjuangkan hak sebagai penyandang hak dan kewajiban adalah berjuang melalui jalur hukum yang berlaku. Hukum merupakan bagian terpenting bagi semua interaksi manusia dalam hidup berbangsa dan bernegara. Terkadang, dalam beberapa kelompok masyarakat ada sekelompok orang yang tidak peduli dengan hukum yang berlaku. Dengan kata lain, masyarakat tersebut merupakan orang-orang yang tidak patuh dengan hukum yang ada. Agar masyarakat mematuhi hukum tentunya diperlukan wibawa hukum. Namun dalam kenyataannya, masyarakat cenderung tidak patuh pada hukum bahkan terkadang masyarakat cenderung menggunakan hukum rimba hal ini terjadi karena tidak adanya wibawa hukum (Nurcahyaningsih, 2015: 1).

Tindakan main hakim sendiri merupakan sesuatu persoalan yang tidak hanya terjadi sekali saja, namun sering, terutama di Indonesia. Mungkin kita masih ingat berapa kasus yang diberitakan melalui media massa baik cetak maupun elektronik. Tidak jarang berita yang disajikan kepada masyarakat adalah sesuatu yang bersifat kekerasan, khususnya kejadian atau peristiwa "penghakiman jalanan" oleh warga masyarakat yang kehidupannya terusik oleh seorang atau sekelompok orang sebagai pelaku kejahatan (Kristanto, 2015: 1). Salah satu contoh yang marak belakangan ini adalah penggrebekan, penganiayaan, dan penelanjangan pasangan yang diduga berbuat mesum di Tangerang (https://news.detik.com/berita/3725750/sejam-mencekam-pasangan-di-tangerangditelanjangi-dan-diarak, diakses Jumat 1 Desember 2017).

Contoh kasus tersebut menandakan bahwa hukum sudah tidak punya tempat lagi di dalam masyarakat kita. Banyak yang meragukan nilai dari hukum tersebut, apakah selama ini hukum sudah adil di dalam kehidupan masyarakat ataukah belum. Dari hal ini dapat disimpulkan bahwa tindakan main hakim sendiri atau disebut juga street justice masih marak di kehidupan masyarakat kita dan menghiasi berbagai berita kriminal di televisi dan media massa di negeri ini. Dari segi hukum sendiri, tindakan tersebut dikategorikan sebagai perbuatan yang dilarang dan diancam pidana, oleh karena itu yang disoroti dalam penulisan tulisan ini adalah bagaimana bisa masyarakat melalaikan hukum dan memilih jalannya sendiri di dalam menghukum seseorang yang di duga melakukan perbuatan kriminal.

Tindakan tersebut bisa diartikan sebagai sebuah kekeresan masyarakat. Kekerasan masyarakat adalah kekerasan yang dilakukan kelompok masyarakat akibat ketidakadilan, penindasan, represi yang dialami oleh kelompok masyarakat. Pada umumnya, kekerasan masyarakat terjadi akibat tekanan ekonomi sehingga masyarakat melakukan kekerasan (Sihombing, 2005: 25). 
Sungguh sangat disayangkan tindakan tersebut. Masyarakat tidak lagi memandang hukum sebagai perisai yang melindungi para warga. Justru hal tersebutlah yang mendorong mereka untuk bertindak sesuai dengan apa yang diyakininya. Hal inilah yang timbul dalam benak penulis, mengapa hal ini bias terjadi di tengah-tengah hukum yang ada di dalam masyarakat? Apakah kehadiran hukum beserta peraangkatnya hanya sebuah formalitas saja? Apakah selama ini dirasa belum adil dalam penegakan hukumnya? Padahal jika dikaji lebih dalam, mereka akan menuntut perlindungan juga ketika mereka diperlakukan seperti hal tersebut.

Sesungguhnya tindakan tersebut telah melanggar asas dalam hukum pidana, yaitu asas praduga tak bersalah, di mana setiap orang dianggap tidak bersalah sebelum ada putusan yang tetap dari pengadilan. Bertitik tolak pada uraian tersebut di atas, maka penulis terdorong untuk mengangkat permasalahan Fenomena Street Justice Di Dalam Kehidupan Bermasyarakat melalui kacamata yuridis-sosiologis. Berdasarkan uraian dari pendahuluan di atas, maka dapat ditarik suatu pertanyaan yang dijadikan rumusan masalah dalam makalah ini, yaitu:

1. Bagaimana pandangan sosiologi hukum terhadap tindakan street justice?

2. Faktor-faktor apa saja yang membuat masyarakat bertindak street justice?

\section{B. METODE PENELITIAN}

Metode penelitian yang digunakan oleh penulis adalah metode penelitian empiris yang berspektif sosiologi hukum yang membahas tentang kesadaran dan kepatuhan hukum. Tujuan dari penulisan ini adalah kita dapat memahami perbuatan street justice dalam perspektif sosiologi hukum dan kita dapat mengetahui penyebab terjadinya perbuatan main hakim sendiri dan serta street justice.

\section{PEMBAHASAN}

Main hakim sendiri dan tindakan street justice tidak diperbolehkan di negara kita ini. Tidak hanya para mahasiswa hukum yang diberi tahu tentang larangan itu, tetapi semua orang pun tahu. Melalui proses sosialisasi, baik pendidikan di rumah, di sekolah, melalui penalaran, pengalaman dan sebagainya, rakyat menjadi tahu, bahwa main hakim sendiri dan tindakan street justice itu tidak diizinkan. Mengeroyok copet beramai-ramai, memukuli pencuri sampai setengah mati, itu semua termasuk larangan (Rahardjo, 1983: 27).

\section{Pandangan Yuridis Sosiologis Tentang Tindakan Street Justice}

Maraknya kejahatan kekerasan di dalam masyarakat seperti tindakan anarkis, main hakim sendiri dan street justice yang mengakibatkan kerusakan harta benda maupun jiwa, kiranya perlu mendapat perhatian khusus oleh pemerintah khususnya aparat penegak hukum. Kejahatan dengan kekerasan (violent) oleh Sanford H. Kadish, didefinisikan sebagai, "all types of illegal behaviour, either threatened or actual that result in damage or destruction of property or in the injury death of an individual". Definisi di atas menyatakan, bahwa kejahatan kekerasan merupakan 
tindakan yang kongkrit, yang berakibat kerugian atau kerusakan harta benda, atau fisik, atau mengakibatkan kematian pada seseorang (Jaya, 2000: 3).

Pada umumnya perilaku kekerasan massa muncul dari situasi konkrit yang sebelumnya didahului oleh sharing gagasan, nilai, tujuan, dan masalah bersama dalam periode waktu yang lama. Masalah bersama adalah faktor penting dan bisa melibatkan perasaan akan bahaya, dendam dan marah. Suatu masalah langsung bisa memicu suatu pemberontakan massa. Bahkan Ted Robert Gurr mengatakan bahwa individu yang memberontak sebelumnya harus memiliki latar belakang situasi seperti terjadinya ketidakadilan, munculnya kemarahan moral dan kemudian memberi respons dengan kemarahan pada sumber penyebab kemarahan tersebut. Selain itu massa juga harus merasakan situasi konkrit dan langsung menjadi pendorong ungkapan kemarahan mereka, sehingga mereka bersedia menerima resiko yang berbahaya (Suwarno, Syani, dan Pairulsyah 2012: 50).

Jauh-jauh hari Profesor Donald Black (dalam The Behavior of Law, 1976) merumuskan bahwa ketika pengendalian sosial oleh pemerintah yang sering dinamakan hukum tidak jalan, maka bentuk lain dari pengendalian sosial secara otomatis akan muncul. Suka atau tidak suka, tindakan-tindakan yang dilakukan oleh individu dan kelompok yang dari optik yuridis dapat digolongkan sebagai tindakan main hakim sendiri (eigenrichting), pada hakikatnya merupakan wujud pengendalian sosial yang dilakukan oleh rakyat. Berbagai tindakan anarki, baik dalam wujud main hakim sendiri maupun tawuran, pertikaian suku, agama, ras, dan antar golongan (SARA), dan jenis lainnya, menjadi fenomena yang kini tampak di berbagai tempat di tanah air. Berbagai tindakan anarkis dan main hakim sendiri itu, celakanya hanya ditanggapi dengan penanganan parsial dan sempit oleh penguasa dan aparat penegak hukum, serta mengabaikan akar masalahnya sendiri. Setiap kasus yang demikian merupakan suatu struktur kompleks posisi-posisi dan hubungan-hubungan sosial. Para petinggi hukum hanya berbicara tentang keberadaan rambu-rambu hukum yang memang ada, tetapi dalam kenyataannya justru tidak berdaya (atau mungkin sengaja tidak diberdayakan oleh sosok petinggi atau penegak hukum tetentu). Kaum realis sering mengemukakan, bahwa "generaly speaking, legal doctrine alone cannnot adequately predict or explain how cases are handled" (secara umum, doktrin hukum semata tidak dapat secara memadai memprediksi atau menjelaskan bagaimana kasus-kasus dapat ditangani). Memang di satu pihak penanganan situasional dibutuhkan, misalnya diharapkan suatu tindakan yang tegas dan profesional oleh aparat penegak hukum terhadap para pelaku anarkis, namun di pihak lain, penanganan secara mendasar pada akar masalahnya juga harus ditangani secara nasional (Ali, 2006: 94).

Seyogyanya disadari bahwa berbagai tindakan anarkis yang terjadi belakangan ini, merupakan perwujudan dari apa yang diistilahkan oleh Smelser sebagai a hostile outbrust (ledakan kemarahan) atau a hostile frustration (ledakan tumpukan kekecewaan). Tingkat kepercayaan warga masyarakat terhadap pranata 
formal, termasuk terhadap law enforcement, sudah teramat buruk. Hal tersebut sudah menjadi adagium yang universal, ketika tingkat kepercayaan warga terhadap penegak hukum itu memburuk, otomatis tingkat tindakan main hakim sendiri akan meningkat, demikian sebaliknya. Untuk itu sangat beralasan dikemukakan bahwa Indonesia membutuhkan suatu strategi raksasa dalam upaya penanggulangan tindakan anarki tersebut. Apa yang dimaksudkan sebagai strategi raksasa ialah pengembalian kepercayaan masyarakat terhadap pemerintahan dan penegak hukum. Berbagai sikap diskriminatif, dilakonkan para penegak hukum negeri ini. Tampak benar oleh hati masyarakat bahwa asas equal justice under law hanya bahan retorika belaka para petinggi hukum. Kondisi keterpurukan hukum di Indonesia saat ini hanya mungkin diatasi jika para penegak hukum lebih banyak bertanya kepada hati nuraninya daripada perutnya, sehingga apa yang disebut benar dan adil oleh masyarakat mampu diimplementasikan oleh para penegak hukum melalui putusan-putusan hukum di pengadilan (Ali, 2006: 94).

Berbagai macam alasan dikemukakan sebagai alasan melakukan main hakim sendiri. Hal yang banyak dijadikan sebagai alasan adalah kurangnya tingkat kepercayaan masyarakat kepada aparat penegak hukum. Masyarakat beranggapan bahwa bila pelaku kejahatan diserahkan kepada aparat penegak hukum maka besar kemungkinan pelaku tersebut akan kembali mengulangi perbuatannya di kemudian hari. Menurunnya ketidak percayaan tersebut menunjukkan rendahnya kemampuan polisi untuk mencegah tindakan main hakim sendiri tersebut. Ketertiban dan kepatuhan terhadap norma kehidupan bermasyarakat diperlukan suatu norma hukum. Hukum sebagai sarana kontrol sosial dalam masyarakat empat fungsi dasar hukum sebagai sarana kontrol sosial dalam kehidupan bermasyarakat, yaitu (Fitriati, 2012: 164):

a. Untuk menetapkan hubungan-hubungan antar anggota masyarakat, dengan menunjukan jenis-jenis perilaku yang ada dalam masyarakat;

b. Menentukan pembagian kekuasaan;

c. Menyelesaikan sikap sengketa; dan

d. Memlihara fungsi-fungsi hubungan antar masyarakat.

Hubungan yang erat antara hukum dan masyarakat ini oleh Durkheim ditunjukan oleh perbedaan bentuk dan cara pelaksanaan hukum dalam suatu struktur sosial masyarakat yang berbeda. Teorinya tentang solidaritas sosial, Durkheim membedakan masyarakat dalam dua jenis yaitu solidaritas mekanik dan solidaritas organik. Solidaritas mekanik ditandai oleh pembagian kerja yang rendah, kesadaran kolektif kuat, idividualisme rendah, hukum yang sifatnya represif sangat dominan, konsendus terhadap pola-pola normatif sangat penting, keterlibatan komunitas dalam menghukum orang yang menyimpang sangat besar, dan bersifat primitif atau pedesaan. Dengan ciri yang demikian, maka hukum ini mendefinisikan setiap perilaku kejahatan sebagai ancaman terhadap solidaritas. Pemberian hukum di sini dilakukan tanpa harus mencerminkan pertimbangan rasional yang mendalam 
mengenai jumlah kerugian secara objektif yang menimpa masyarakat dan juga bukan merupakan pertimbangan yang diberikan untuk menyesuaikan hukuman dengan kejahatannya. Hukuman tersebut cenderung mencerminkan dan menyatakan kemarahan kolektif (Fitriati, 2012: 164).

Solidaritas organik ditandai oleh pembagian kerja yang tinggi, kesadaran kolektif rendah, hukum yang sifatnya restitutif lebih dominan, individualis tinggi, lebih mementingkan konsensus pada nilai-nilai abstrak dan umum, badan-badan kontrol sosial yang menghukum orang yang menyimpan, dan bersifat industrialperkotaan. Penerapan hukuman dalam solidaritas mekanik lebih bertujuan untuk memulihkan perilaku masyarakat agar sesuai dengan norma-norma yang berlaku dalam masyarakat (Fitriati, 2012: 164).

Sering dikatakan, tindakan street justice yang anarkis itu identik dengan ketidakpercayaan pada aparat penegak hukum. Daripada menyerahkan segala sesuatunya kepada polisi dengan kemungkinan tidak mendapatkan keadilan sebagaimana dipersepsikan, maka lebih baik merekalah yang menjadi polisi, jaksa sekaligus hakimnya. Perihal ketidakpercayaan itu, diduga bisa benar namun bisa pula tidak. Dikatakan benar karena, betapapun hendak disangkal, nyatanya ada saja oknum polisi yang menyalahgunakan wewenangnya. Alih-alih melakukan penyidikan dan pemberkasan, yang kemudian terjadi adalah transaksi uang dari tersangka kepada oknum polisi tersebut agar bisa ditahan luar atau bahkan ditangguhkan perkaranya. Tetapi hal itu bisa pula dikatakan tidak benar, mengingat yang sebenarnya dikeluhkan oleh para anarkis tadi adalah "kinerja hukum pada umumnya yang tidak memenuhi harapan". Ada yang mengatakan "penegak hukum bekerja lambat", tetapi bukankah jaksa dan hakim itu bekerja jauh lebih lambat dibanding polisi? Ada pula yang mengatakan, "tuntutan buat tersangka rendah", tetapi bukankah menuntut itu bukan pekerjaan polisi? Atau dikatakan pula, "pelaku akhirnya bisa lenggang-kangkung lagi”, tetapi bukankah memutuskan perkara juga bukan pekerjaan polisi? Hanya saja, selaku personifikasi hukum dan elemen terdepan dalam proses penegakkan hukum, polisi memang kerap terpaksa menerima getahnya mengingat polisilah yang secara langsung berurusan dengan tindak anarkis itu dan bukan aparat hukum lainnya. Juga perlu disebutkan bahwa, terdapat kecenderungan yang semakin menyulitkan kepolisian pada umumnya berkaitan dengan pemeliharaan ketertiban umum (Meliala, 2001: 10).

Kekerasan untuk membela diri atau main hakim sendiri (vigilante) merupakan sesuatu tindakan masyarakat untuk mendapatkan keadilan di saat aparat atau negara tidak efektif menegakkan hukum. Main hakim sendiri adalah perbuatan melampaui hukum yang menerabas batas baik dan buruk serta benar dan salah. Bersamaan dengan maraknya main hakim sendiri, berubah pula pandangan masyarakat terhadap batas-batas moralitas (Ali, 2008: 1). 
Merujuk pada pendapat di atas, maka tindakan main hakim sendiri yang dilakukan masyarakat merupakan pesan atau sinyal yang dikirimkan kepada penegak hukum, untuk secara lebih efektif dan atau lebih keras dan tegas dalam penegakan hukum dan oleh karenanya masyarakat dapat kembali memperoleh rasa aman dan ketenangan. Pembiaran terhadap tindakan main hakim sendiri, sama artinya dengan negara memupuk terbentuknya budaya hukum rimba di tengah masyarakat. Negara harus mencegah masyarakat untuk menegakkan hukum dengan cara-cara yang justru melanggar hukum. Pelaksanaan sanksi harus menjadi monopoli negara. Perorangan tidak diperkenankan melaksanakan sanksi untuk menegakkan hukum. Memukul orang yang telah menipu kita, menyekap orang yang tidak mau melunasi hutang, "mencuri" sepeda motor milik sendiri dari pencurinya, memberantas pemerkosaan dengan memperkosa kembali pelaku, semuanya merupakan tindakan main hakim sendiri, yang pelakunya harus dihukum agar tercipta ketertiban atau ketaatan terhadap hukum di tengah masyarakat (Subhan, Achmad, dan Syarifuddin, 2014: 74-75).

\section{Faktor-Faktor Penyebab Tindakan Street Justice}

Berdasarkan analisa uraian di atas, dapat disimpulkan bahwa penyebab tindakan main hakim sendiri ialah rendahnya kesadaran hukum dari setiap orang itu sendiri. Karena kesadaran hukumnya rendah, maka beberepa orang tersebut menempuh jalan pintas dengan melakukan street justice. Akibat dari tindakan tersebut adalah korban dari tindakan street justice akan menerima perlakuan yang tidak menyenangkan, bahkan mereka akan mendapat tindakan penganiayaan yang beragam. Hal tersebutlah yang menjadikan hukum seperti tidak berdaya di dalam masyarakat.

Pada umumnya kesadaran masyarakat terhadap hukum yang tinggi mengakibatkan para warga masyarakat mematuhi ketentuan peraturan perundang-undangan yang berlaku. Sebaliknya, apabila kesadaran masyarakat terhadap hukum rendah, derajat kepatuhannya juga akan rendah.

Kemajuan pembangunan yang dicapai oleh masyarakat Indonesia saat ini secara umum dapat dikategorikan pada struktur masyarakat bentuk solidaritas organik. Dengan kemajuan ini, tentunya norma hukum yang dianut lebih bersifat restritutif. Namun melihat perilaku main hakim sendiri yang dilakukan oleh masyarakat, tindakan tersebut dapat dikategorikan sebagai penerapan hukum yang berlaku pada masyarakat yang memiliki karakteristik solidaritas mekanik. Ketidak selarasan antara kemajuan zaman dengan praktik pelaksanaan hukum ini selanjutnya dapat dikategorikan sebagai penyimpangan (Fitriati, 2012: 165).

Penyimpangan atau ketidaksesuaian yang terjadi dalam masyarakat ini, dalam teori sosiologi disebut sebagai anomie, yaitu suatu keadaan di mana nilai- nilai dan norma-norna semakin tidak jelas lagi dan kehilangan relevansinya. Tindakan main hakim sendiri, dengan demikian dapat dikategorikan sebagai anomie, atau dalam 
kasus main hakim sendiri ini terjadi ketidaksesuaian dalam penerapan fungsi hukum dengan tujuan yang diinginkan oleh masyarakat. Pelaksanaan fungsi hukum oleh lembaga hukum dipandang oleh masyarakat belum memenuhi rasa keadilan masyarakat, sehingga masyarakat menjalankan hukumnya sendiri. Berlarutnya penyelesaian berbagai kasus pelanggaran hukum yang tanpa ujung telah menghilangkan kepercayaan masyarakat terhadap institusi dan perangkat hukum (Fitriati, 2012: 165).

Tindakan individu atau massa untuk main hakim sendiri terhadap pelaku kejahatan pada hakikatnya merupakan salah satu bentuk pengendalian sosial oleh masyarakat. Perilaku menyimpang dan anomie dalam bentuk main hakim sendiri, sebagai suatu penyakit masyarakat, tentunya harus segera diobati. Untuk menemukan obat yang tepat pertama kali perlu dikenali adalah akar permasalahan munculnya tindak kekerasan atau main hakim sendiri tersebut. Apabila akar masalahnya adalah ketidakpercayaan terhadap pranata hukum, maka fungsi hukum seperti yang dikemukakan di muka perlu dilaksanakan secara konsekuen. Upaya ini pada akhirnya akan menumbuhkan kewibawaan dan kepastian hukum yang memenuhi rasa keadilan masyarakat. Sedangkan apabila tindak kekerasan itu berakar pada ketidakadilan dan ketidakpastian masyarakat oleh struktur kekuasaan (penguasa), maka obat yang tepat untuk itu adalah "pencairan" struktur kekuasaan yang menjadi sumbemya (Fitriati, 2012: 165).

\section{a. Kesadaran Hukum Masyarakat Yang Rendah Sebagai Penyebab Tindakan Main Hakim Sendiri}

Kesadaran hukum menurut Paul Scholten adalah "rechtbewustzijn is het in eider mens levend bewuszjin van wat recht is of behoort tezijn", yang berarti bahwa kesadaran hukum itu adalah suatau kesadaran yang ada di dalam kehidupan manusia untuk selalu patuh dan taat kepada hokum (Abdurrahman, 1979: 29). Kesadaran hukum merupakan konsepsi abstrak di dalam diri manusia, tentang keserasian antara ketertiban dan ketentraman yang dikehendaki atau sepantasnya. Kesadaran hukum sering dikaitkan dengan pentaatan hukum, pembentukan hukum, dan efektivitas hukum. Kesadaran hukum merupakan kesadaran nilai-nilai yang terdapat dalam manusia tentang hukum yang ada. Kesadaran hukum berkaitan dengan kepatuhan hukum, hal yang membedakannya yaitu dalam kepatuhan hukum ada rasa takut akan sanksi (Rosana, 2014: 3).

Menurut Iswanto tindakan main hakim sendiri terjadi karena keretakan hubungan antara penjahat dan korban yang tidak segera diselesaikan atau diselesaikan dengan hasil yang dirasakan tidak adil bagi korban. Korban merasa kepentingan dan hak-haknya diinjak-injak bahkan dihancurkan oleh penjahat maka korban berkewajiban untuk mempertahankan kepentingannya dan hak-haknya terhadap penjahat secara langsung dengan jalan kekerasan bahkan mungkin lebih keras dan lebih kejam dari cara yang digunakan oleh pelaku (Widayati, 2015: 2). 
Paham kesadaran hukum yang sebenarnya berkisar pada diri warga-warga masyarakat merupakan suatu faktor yang menentukan bagi sahnya hukum. Pada awalnya masalah kesadaran hukum timbul di dalam proses penerapan daripada hukum positif tertulis. Dalam kerangka proses tersebut timbul masalah, oleh karena adanya ketidak sesuaian antara dasar sahnya hukum (yaitu pengendalian sosial dari penguasa atau kesadaran warga masyarakat) dengan kenyataan-kenyataan dipatuhinya (atau tidak ditaatinya) hukum positif tertulis tersebut. Hal itu merupakan suatu keadaan yang dicita-citakan atau dikehendaki, bahwa ada keserasian proporsional antara pengendalian sosial oleh penguasa, kesadaran warga masyarakat dan kenyataan dipatuhinya hukum positif tertulis. Ide tentang kesadaran warga masyarakat sebagai dasar sahnya hukum positif tertulis diketemukan di dalam ajaran-ajaran tentang Rechtgefuhl atau Rechtbewusstsein yang intinya adalah, bahwa tak ada hukum yang mengikat warga-warga masyarakat kecuali atas dasar kesadaran hukumnya (Soekanto, 1982: 145).

Tentang masalah ini Krabbe menyatakan, bahwa selain daripada kekuasaan dewa-dewa dan wewenang publik, maka ada wewenang lain yaitu kesadaran manusia (Soekanto, 1982: 145). Kesadaran manusia tersebut telah begitu menjiwai dan mendarah daging, sehingga mempunyai kekuatan yang lebih besar daripada wewenang biasa yang didasarkan pada prestise. Kenyataan tersebut semakin berkembang, terutama dalam kehidupan spiritual manusia dewasa ini. Hal yang sama pernah pula dikemukakan oleh Fuller, sebagai berikut (Soekanto, 1982: 145):

"To embark on the enterprrise of subjecting human conduct to the governance of rules involves of. Necessity a commitment to the view that man is, or can become, a responsible agent, capable of understanding and following rules, and anwrable for his defaults. Every departure from the principles of the law's'inner morality is an affront to man's'dignity as a responsible agent. To judge his actions by unpublished or retrospective laws, or to order him to do an act that is imposible, is to convey to him your indifference to his powers of self determination"

Permasalahan tadi juga pernah dikemukakan oleh Selznick, yang menyatakan bahwa (Soekanto, 1982: 145):

"...a conception of law as the manifestation of awesome authority encourages feelings of deference and is compatible with much arbitrary rule. In a community that aspires to ahigh order of legality obedience to law is not submassive compliance. The obligation to obey tje law is closely tied to the defensibilitu of the rules themselves and of the official decisions that enforce them"

Menurut sejarahnya, maka permasalahan kesadaran hukum tersebut timbul di dalam kerangka mencari dasar sahnya hukum yang merupakan konsekuensi dari masalah yang timbul di dalam penerapan tata hukum atau hukum positif tertulis. Masalahnya kemudian berkisar pada apakah sahnya hukum adalah pengendalian dari penguasa atau kesadaran warga masyarakat. Masalahnya timbul, oleh karena 
ada hukum yang tidak ditaati oleh warga-warga masyarakat. Jadi, masalahnya di sini terpusat pada tata hukum. Hal itu sangat penting untuk dapat mengukur efektivitas undang-undang tersebut, yang antara lain tergantung pada ketaatan atau kepatuhan para warga masyarakat, termasuk para pemimpinnya. Ada sementara anggapan yang menyatakan, bahwa kesadaran hukum bukan merupakan suatu penilaian hukum terhadap peristiwa-peristiwa konkrit. Kesadaran hukum merupakan suatu penilaian terhadap apa yang dianggap sebagai hukum yang baik dan/atau hukum yang tidak baik. Penilaian terhadap hukum tersebut meliputi penilaian apakah hukum tersebut adil atau tidak adil, oleh karena keadaan yang diharapkan oleh warga masyarakat. (Soekanto, 1989: 196).

Jadi, kesadaran hukum tersebut merupakan suatu proses psikis yang terdapat pada diri manusia, yang mungkin timbul dan mungkin pula tidak timbul. Akan tetapi, tentang asas kesadaran hukum, itu terdapat pada setiap manusia, oleh karena setiap manusia mempunyai rasa keadilan. Sudah tentu, bahwa penilaian tentang adil atau tidak adilnya suatu hukum positif tertulis senantiasa tergantung pada taraf persesuaian antara rasa keadilan pembentuk hukum dengan rasa keadilan warga masyarakat yang kepentingan-kepentingannya diatur oleh hukum tadi. Secara logis, maka prosesnya adalah, bahwa seseorang harus memahami hukum tersebut, sebelum dia mempunyai kesadaran hukum. Dengan demikian, kalau konnsepsi di atas diikuti, maka adalah kurang tepat untuk menyatakan bahwa tata hukum Indonesia harus dibentuk atas dasar kesadaran hukum masyarakat. Mungkin lebih tepat adalah, bahwa tata hukum Indonesia harus dibentuk atas dasar asas kesadaran hukum warga masyarakat, yaitu rasa keadilannya (Soekanto, 1989: 196).

\section{b. Penyebab Kesadaran Hukum Masyarakat Rendah}

Fenomena street justice terjadi karena dua faktor, yakni faktor internal (dari dalam diri warga masyarakat sendiri), dan faktor eksternal (salah satunya ketidakpercayaan masyarakat terhadap sistem hukum (aparat, lembaga penegak hukum, atau hukumnya itu sendiri, atau prakek penegakan hukunnya, yang "tajam ke bawah, tumpul ke atas".

1) Faktor Internal yang mempengaruhi kesadaran hukum masyarakat rendah

Faktor ini adalah faktor yang berasal dari dalam diri masyatrakat, dimana factor ini adalah faktor yang terpenting di dalam membentuk kesadaran hukum masyarakat tersebut.

\section{a) Faktor Ketidakpercayaan Masyarakat kepada Penegak Hukum}

Saat kini, masyarakat mulai geram dengan tindakan para aparatur penegak hukum (oknum), bukan terhadap hukum yang hidup di tengah-tengah bermasyarakat. Akan tetapi bentuk perlawanan masyarakat terhadap para penegak hukum. Terbukti dengan maraknya pelanggaran terhadap hukum itu sendiri, karena masyarakat sudah tidak percaya lagi dengan para penegak hukum yang menjadi pejundang terhadap hukum yang dijadikan panglima di Negara Indonesia. 
Dengan maraknya pelanggaran terhadap hukum, mulai dari hal-hal yang sepeleh hingga pada persoalan yang besar terlihat jelas dewasa ini di tengah-tengah masyarakat yang sepertinya sengaja diperlihatkan di depan umum untuk diakses ke publik. Ini menjadi indikasi yang tidak baik untuk para penegak hukum yang harus berbenah sedini mungkin untuk mengembalikan citra hukum di masyarakat. Kondisi peradilan di Indonesia dalam penegakan hukum saat ini masih dianggap kurang memenuhi harapan dan perasaan keadilan masyarakat. Lembaga peradilan yang seharusnya menjadi benteng terakhir untuk mendapatkan keadilan sering tidak mampu memberikan keadilan yang didambakan. Banyaknya pelaku kejahatan yang lolos dari jerat hukum ditambah kondisi penegak hukum yang terlibat kasus hukum seperti kasus suap dan sebagainya. Akibatnya, rasa hormat dan kepercayaan terhadap lembaga ini nyaris tidak ada lagi sehingga semaksimal mungkin orang tidak menyerahkan persoalan hukum yang mereka alami ke penegak hukum dan lebih memilih menciptakan hukum sendiri seperti menghakimi sendiri pelaku tindak pidana yang mereka tangkap (Supianto, 2014: 52).

Saat ini sedang kondisi di mana tatanan sistem hukum yang dijalankan oleh pemerintah dalam arti luas tidak lagi dipercaya oleh masyarakat. Kondisi ini memiliki ciri-ciri dimana hukum tidak lagi dipandang sebagai human institution yang dapat memberikan rasa perlindungan hak-haknya sebagai warga negara. Oleh karena itu, harus segera dilakukan langkah-langkah untuk melakukan pengembalian kepercayaan tersebut.

Berkembangnya ketidakpercayaan masyarakat terhadap aparat penegak hukum yang tidak dapat menunjukkan wibawa dalam penegakan hukum justru sebaliknya muncul kasus-kasus baru yang hampir sama dengan masa sebelumnya, sehingga pemerintah dicap tidak mampu menjalankan supremasi hukum dengan baik dan benar, atau runtuhnya kepercayaan pada apparat penegak hukum. Masyarakat jenuh terhadap hukum yang hanya menjadi slogan tanpa penerapan yang konsisten dan adil.

b) Kurangnya Pemahaman dan Kesadaran Masyarakat Tentang Hukum

Dikatakan bahwa, "Asas kesadaran hukum itu ialah bahwa tiap-tiap warga Negara Indonesia harus selalu sadar dan taat kepada hukum dan mewajibkan negara untuk menegakkan dan menjamin kepastian hukum." Pengertian yang diberikan di atas menurut hemat penulis adalah pengertian dalam arti operasional, bukan dalam arti "asas" yang melandasi norma hukum yang kita maksudkan semula. Jika demikian halnya maka kita perlu mencari pengertian tentang kesadaran hukum agar tidak terjadi suatu pemahaman yang salah. Menurut Scholten, "kesadaran hukum itu adalah tidak lain dari pada suatu kesadaran yang ada dalam kehidupan manusia untuk selalu patuh dan taat kepada hukum" (Chairruddin, 1991: 105). Tidak jauh dengan apa yang disimpulkan Scholten, dari Simposium Kesadaran Hukum Masyarakat dalam Masa Transisi memberikan batasan bahwa pengertian 
kesadaran hukum itu meliputi, pengetahuan tentang hukum, penghayatan terhadap hukum, dan ketaatan kepada hukum (Chairruddin, 1991: 106).

Untuk dapat menghayati dan mentaati norma hukum, orang harus terlebih dahulu mengetahuinya. Hukum yang disusun tanpa memperhatikan kepada aspek ini, justru akan menimbulkan kesulitan dalam penerapannya. Orang yang mengetahui tentang sesuatu justru akan lebih mudah untuk memahami, sehingga menimbulkan keinginan untuk menghayati dan mematuhinya, ketimbang orang yang tidak mengetahui sama sekali. Jika dalam suatu masyarakat masing-masing individu telah mengetahui sampai pada tingkat mentaatinya, maka terciptalah dalam masyarakat itu perasaan kolektif untuk menghormati kaidah hukum. Agaknya dalam kesempatan ini perlu kami turunkan apa yang dikatakan oleh Bertrand Russel, beliau mengatakan, "Hukum hampir-hampir tidak ada gunanya apabila tidak didukung oleh perasaan daripada publik atau masyarakat" (Chairruddin, 1991: 107).

Peranan hukum di dalam masyarakat sebagaimana tujuan hukum itu sendiri dalam menjamin kepastian hukum dan keadilan, dalam kehidupan masyarakat senantiasa terdapat perbedaan antara pola-pola perilakunya atau tata kelakuan yang berlaku dalam masyarakat dengan pola-pola perilaku yang dikehendaki oleh norma-norma (kaidah) hukum. Hal ini dapat menyebabkan timbulnya suatu masalah berupa kesenjangan sosial sehingga pada waktu tertentu cenderung terjadi konflik dan ketegangan-ketegangan sosial yang tentunya dapat mengganggu jalannya perubahan masyarakat sebagaimana arah yang dikehendaki. Keadaan demikian terjadi oleh karena tidak adanya kesadaran hukum yang diciptakan dan diharapkan menjadi pedoman (standar) dalam bertindak bagi masyarakat, sehingga cenderung tidak ada ketaatan hukum (Nurcahyaningsih, 2015: 3).

Kesadaran hukum pada masyarakat bukanlah merupakan proses yang sekali jadi, melainkan merupakan suatu rangkaian proses yang terjadi tahap demi tahap sebagai berikut:

i. Tahap pengetahuan hukum

Dalam hal ini, merupakan pengetahuan seseorang berkenaan dengan perilaku tertentu yang diatur oleh hukum tertuluis, yakni tentang apa yang dilarang atau apa yang dibolehkan

ii. Tahap pemahaman hukum

Yang dimaksud adalah bahwa sejumlah informasi yang dimiliki seseorang mengenai isi dari aturan hukum (tertulis), yakni mengenai isi, tujuan, dan manfaat dari peraturan tersebut.

iii. Tahap sikap hukum (legal attitude)

Merupakan suatu kecenderungan untuk menerima atau menolak hukum karena adanya penghargaan atau keinsyafan bahwa hukum tersebut bermanfaat atau tidak bermanfaat bagi 
kehidupan manusia. Dalam hal ini sudah ada elemen apresiasi terhadap aturan hukum.

iv. Tahap Pola Perilaku Hukum

Yang dimaksud adalah tentang berlaku atau tidaknya suatu aturan hukum dalam masyarakat. Jika berlaku suatu aturan hukum, sejauh mana berlakunya dan sejauh mana masyarakat mematuhinya (Fuady, 2007: 80).

\section{c) Faktor Psikologis}

Pada konteks psikologi sosial, main hakim sendiri tidak dapat dilepaskan dari agresivitas dan psikologi massa. Kedua hal tersebut memiliki hubungan yang saling berkaitan satu dengan yang lainnya. Agresivitas atau sifat agresif secara bahasa berasal dari kata agresi yang memiliki makna suatu perbuatan yang dapat melukai orang lain. Agresi dapat dibedakan menjadi dua, yakni agresi positif dan agresi negatif. Agresi positif merupakan tindakan agresi yang dapat dibenarkan sebagai akibat dari pembelaan seseorang terhadap ancaman atau serangan. Sedangkan agresi negatif adalah serangan atau perbuatan dilakukan secara sengaja terhadap orang lain dengan tujuan untuk melukai orang yang diserang. Agresi tidak muncul dengan tanpa sebab. Ada dua hal yang dapat menyebabkan timbulnya agresi, yakni adanya gangguan dan frustasi. Gangguan adalah segala sesuatu yang dapat menimbulkan perasaan tidak tenang, terancam atau bahkan terganggunya seseorang akibat sesuatu tindakan atau perbuatan yang dilakukan oleh orang atau pihak lain. Sedangkan frustasi adalah perasaan kecewa akibat kegagalan-kegagalan yang dialami oleh seseorang. Keberadaan salah satu dari atau bahkan kedua hal itu (gangguan dan frustasi) akan dapat memicu agresivitas seseorang (Naim, 2015: 67).

Agresivitas akan semakin besar manakala dilakukan oleh kelompok orang (massa). Ini dikarenakan agresivitas aktif orang-orang dalam suatu kelompok massa akan mampu menjadi pendorong munculnya agresivitas orang-orang yang sebelumnya pasif dalam kelompok massa tersebut. Massa pasif yang semula raguragu atau khawatir akan berbalik keyakinan untuk berani ikut dalam main hakim sendiri. Hal inilah yang kemudian memicu faktor ikut-ikutan dalam main hakim sendiri yang dilakukan oleh beberapa orang pada kasus main hakim sendiri ketika menemukan sebuah tindak pidana yang terjadi di dalam kehidupan bermasyarakatnya (Naim, 2015: 68).

2) Faktor external yang mempengarugi kesadaran hukum masyarakat rendah.

Faktor ini adalah faktor yang berasal dari luar diri masyatrakat, dimana faktor ini biasanya bersumber dari kehidupan sosiologis masyarakat dimana mereka tinggal.

\section{a. Faktor Lemahnya Penegakan Hukum}

Maraknya tindakan main hakim sendiri ini sebagian besar disebabkan karena penanganan kasus seperti ini banyak yang tidak terselesaikan, dalam artian banyak kasus yang dibiarkan dan tidak ditindak lanjuti oleh aparat penegak hukum dan 
sering kali tidak memenuhi rasa keadilan masyarakat sehingga timbul pemicu yang menyebabkan suatu ledakan kemarahan masyarakat. Kenyataan tersebut di atas, mengakibatkan masyarakat berkesimpulan bahwa main hakim sendiri merupakan tindakan tegas dalam memberikan sanksi kepada pelaku kejahatan. Masyarakat merasa semakin mudah menumpahkan kemarahannya kepada pelaku kejahatan dengan melakukan pengeroyokan beramai-ramai dengan tindakan fisik, mulai dari pemukulan ringan hingga menyebabkan meninggalnya si korban atau pelaku tindakan pidana. Hal ini dikarenakan rendahnya pengetahuan hukum, masih adanya perilaku masyarakat lebih suka melakukan penghukuman sendiri pada pelaku kejahatan karena bagi masyarakat penghukuman seperti itu lebih efektif (Nurcahyaningsih, 2015: 5).

\section{b. Substansi Hukum}

Hukum merupakan salah satu faktor yang mempengaruhi kesadaran hukum masyarakat. Terdapat adigium dalam ilmu hukum, bahwa setiap orang dianggap tahu hukum pada saat hukum dinyatakan berlaku, sehingga secara logika hukum tersebut dapat diterapkan setelah aturan tersebut dinyatakan berlaku. Hukum dibuat untuk dilaksanakan, hukum tidak lagi disebut hukum manakala tidak dilaksanakan dalam masyarkat (Tagel, 2013: 10).

\section{c. Struktur Hukum}

Struktur berupa kelembagaan yang diciptakan oleh sistem hukum untuk mendukung bekerjanya sistem hukum itu sendiri. Di sini yang disebut struktur hukum yang dimaksud adalah aparat hukum, seperti kepolisian, kejaksaan dan hakim. Semua aparat tersebut saling bersinergi agar dapat menghukum pelaku sesuai nilai keadilan yang dijunjung tinggi oleh hukum. Dari ketiga apparat tadi, yang paling utama adalah kepolisian. Hal ini disebabkan karena kepolisianlah yang bersinggungan pertama kali dengan tindak kejahatan yang ada di dalam masyarakat. Jadi, harapan masyarakat terhadap Lembaga kepolisian sangatlah besar, agar tindak kejahatan yang ada di masyarakat bisa segera diproses dan dihukum sesuai dengan undang-undang yang berlaku. Jika hal ini terkesan lamban atau mandek, maka masyarakat timbul sikap bar-bar untuk menghakimi pelaku sesuai dengan kehendak dan keinginan mereka.

\section{d. Budaya Hukum}

Menurut Bernard Arief Sidharta, bahwa "budaya hukum adalah keseluruhan nilai, sikap, perasaan dan perilaku para warga masyarakat termasuk pejabat pemerintahaan terhadap atau berkenaan dengan hukum" (Sidharta, 1999: 76). Kaitannya dengan kesadaran hukum, budaya hukum dapat diartikan sebagai nilainilai atau perilaku masyarakat atau kebiasaan masyarakat dalam mematuhi atau mentaati aturan hukum. Seseorang dianggap mempunyai taraf kesadaran hukum yang tinggi apabila perilaku nyatanya sesuai dengan hukum yang berlaku. Hal ini dapat dilihat dari pendapat Lawrence M. Friedman yang menyatakan bahwa "attitudes and feelings that predispose groups and individuals to turn to or against the law" (Tagel, 2013: 12). 
Oleh karenanya, maka taraf kesadaran hukum yang tinggi didasarkan pada kepatuhan hukum yang menunjukkan sampai sejauh manakah perilaku nyata seseorang sesuai dengan hukum yang berlaku. Akan tetapi tidak setiap orang yang mematuhi hukum mempunyai kesadaran hukum yang tinggi. Hal ini disebabkan oleh karena faktor-faktor penyebab terjadinya kepatuhan hukum harus pula dipertimbangkan. Faktor-faktor yang menyebabkan seseorang mematuhi hukum tersebut adalah (Soekanto, 1990: 30):

i. $\quad$ Rasa takut pada sanksi hukum yang akan dijatuhkan apabila melanggar.

ii. Untuk memelihara hubungan baik dengan penguasa.

iii. Untuk memelihara hubungan baik dengan rekan-rekan kelompok.

iv. Oleh karena kepentingan pribadi terjamin oleh hukum.

v. Oleh karena hukum sesuai dengan nilai-nilai yang dianut, terutama nilai-nilai keterkaitan dan ketentraman.

Menurut Friedman yang dikutip oleh Erman Rajagukguk, bahwa substansi dan aparatur saja tidak cukup untuk berjalannya sistem hukum. Friedman menekankan kepada pentingnya budaya hukum (Legal Culture). Menurutnya, sistem hukum tanpa budaya hukum yang mendukungnya serupa dengan ikan di dalam baskom, yang tidak bisa berenang. Kalau sistem hukum diumpamakan sebagai suatu pabrik, substansi itu adalah produk yang dihasilkan, aparatur adalah mesin yang menghasilkan produk. Sedangkan budaya hukum adalah manusia yang mengetahui kapan mematikan dan menghidupkan mesin, yang tahu memproduksi barang apa yang dikehendakinya. Konteksnya adalah mengapa orang taat atau tidak taat pada hukum? Mengapa orang lebih suka menyelesaikan sengketanya tidak di pengadilan, tetapi lebih suka menyelesaikan sengketanya di luar pengadilan? Lebih lanjut Friedman menyatakan, bahwa budaya hukum tergantung pada sub kultur individu yang bersangkutan. Sub kultur tersebut dipengaruhi oleh berbagai faktor, seperti agama, ekonomi, budaya, nilai yang diterima, pendidikan, posisi, dan kepentingankepentingan (Rajagukguk, 2004: 13).

Membangun kesadaran hukum tidaklah mudah, tidak semua orang memiliki kesadaran tersebut. Hukum sebagai fenomena sosial merupakan institusi dan pengendalian masyarakat. Di dalam masyarakat dijumpai berbagai institusi yang masing-masing diperlukan untuk memenuhi kebutuhan-kebutuhannya dan memperlancar jalannya pemenuhan kebutuhan-kebutuhan tersebut. Karena fungsinya tersebut masyarakat perlu kehadiran institusi untuk membantu pemahaman kesadaran hukum. Beberapa faktor yang mempengaruhi masyarakat tidak sadar akan pentingnya hukum adalah adanya ketidakpastian hukum, peraturan-peraturan yang bersifat statis, dan tidak efisiennya cara-cara masyarakat untuk mempertahankan peraturan yang berlaku (Nurcahyaningsih, 2015: 3). 
Menurut sejarahnya, permasalahan kesadaran hukum timbul di dalam kerangka mencari dasar sahnya hukum yang merupakan konsekuensi dari masalah yang timbul di dalam penerapan tata hukum atau hukum positif tertulis. Masalahnya kemudian berkisar pada apakah sahnya hukum adalah ditentukan berdasarkan penguasa atau berawal dari kesadaran warga masyarakat. Masalahnya timbul, oleh karena ada hukum yang tidak ditaati oleh warga-warga masyarakat. Hal itu sangat penting untuk dapat mengukur efektivitas undang-undang tersebut, yang antara lain tergantung pada ketaatan atau kepatuhan para warga masyarakat, termasuk para pemimpinnya. Ada sementara anggapan yang menyatakan, bahwa kesadaran hukum bukan merupakan suatu penilaian hukum terhadap peristiwa-peristiwa konkrit. Kesadaran hukum merupakan suatu penilaian terhadap apa yang dianggap sebagai hukum yang baik dan/atau hukum yang tidak baik. Penilaian terhadap hukum tersebut meliputi penilaian apakah hukum tersebut adil atau tidak adil, oleh karena keadaan yang diharapkan oleh warga masyarakat. Apabila tata hukum yang ada dipakai sebagai titik tolak, maka pungutan liar secara legalitas bertentangan dengan undang-undang maupun hukum, namun tidak menyentuh pada ranah kesadaran hukumnya. Jadi, kesadaran hukum tersebut merupakan suatu proses psikis yang terdapat pada diri manusia, yang mungkin timbul dan mungkin pula tidak timbul. Asas kesadaran hukum terdapat pada setiap manusia, oleh karena setiap manusia mempunyai rasa keadilan (Soekanto, 1983: 124).

Sudah tentu, bahwa penilaian tentang adil atau tidak adilnya suatu hukum positif tertulis, senantiasa tergantung pada taraf persesuaian antara rasa keadilan pembentuk hukum dengan rasa keadilan warga masyarakat yang kepentingankepentingannya diatur oleh hukum tadi. Secara logis, maka prosesnya adalah bahwa seseorang harus memahami hukum tersebut sebelum dia mempunyai kesadaran hukum. Jadi, tanpa rasa keadilan, maka kurang tepat untuk menyatakan bahwa tata hukum Indonesia harus dibentuk atas dasar kesadaran hukum masyarakat. Tata hukum akan menyebabkan masyarakat untuk patuh karena wujud rasa keadilan dari hukum tersebut (Soekanto, 1989: 197).

Asumsi bahwa kesadaran hukum warga masyarakat terhadap hukum yang ius constitutum mengakibatkan para warga masyarakat mematuhi ketentuan peraturan perundang-undangan yang berlaku. Sebaliknya, apabila keadaran hukum warga masyarakat terhadap hukum rendah, derajat kepatuhannya juga rendah. Hukum berasal dari masyarakat dan hidup serta berproses di dalam masyarakat. Maka, kesadaran di dalam pembaharuan hukum tidak mungkin dilepaskan secara mutlak dari masyarakat. Kenyataan yang ada seperti yang dihadapi Indonesia yaitu masyarakatnya yang heterogen dengan tingkat bentuk masyarakat yang berbedabeda, mulai dari yang sederhana sampai pada masyarakat yang kompleks, maka akan dihadapkan pada pola diferensiasi yang berbeda-beda pula yang akhirnya membawa akibat pada struktur masing-masing masyarakat. Pada masayarakat yang sederhana, hukum timbul dan tumbuh bersama-sama dengan pengalaman- 
pengalaman hidup warga masyarakatnya. Di sini penguasa lebih banyak mengesahkan atau menetapkan hukum yang sebenarnya hidup di masyarakat. Akan tetapi hal yang sebaliknya agaknya terjadi pada masyarakat yang kompleks. Kebhinekaan masyarakat yang kompleks menyebabkan sulit untuk memungkinkan timbulnya hukum dari bawah. Diferensiasi yang tinggi dalam strukturnya membawa konsekuensi pada aneka macam kategori dan kepentingan dalam masyarakat dengan kepentingan-kepentingan yang tidak jarang saling bertentangan. Walaupun hukum datang dan ditentukan dari atas, sumbernya tetap dari masyarakat (Hartanto, 2015: 477).

\section{KESIMPULAN}

Jika ditinjau dari segi sosilogis, tindakan street justice ini menandakan bahwa masyarakat sudah tidak percaya lagi dengan hukum. Hukum yang seharusnya melindungi mereka justru menjadi hal yang menghambat dalam penyelesaian perkara yang ada di masyarakat. Hal ini tidaklah timbul secara spontan, akan tetapi muncul karena adanya dorongan dari masyarakat karena menahan rasa kesal mengapa proses penyelesaian suatu perkara lama, dan terkesan lamban bahkan jalan di tempat.

Tindakan street justice disebabkan karena rendahnya kesadaran hukum yang ada pada masyarakat. Karena tidak ada kesadaran hukum di dalam masyarakat, maka masyarakat cenderung menggunakan hukum jalanan, atau yang biasa disebut street justice di dalam menyelesaikan permasalahan hukum di lingkungannya. Kesadaran hukum itu terbentuk oleh beberapa faktor yang ada di masyarakat. Antara lain karena setiap warga masyarakat yang hidup di suatu lingkungan masyarakat didoktrin untuk mematuhi hukum, entah itu sesuai atau tidak dengan imbalannya.

Rendahnya kesadaran hukum ini terbentuk oleh dua faktor yang ada, yaitu faktor internal dan faktor eksternal. Faktor internal adalah faktor yang ada pada diri masyarakat, seperti faktor ketidakpercayaan masyarakat kepada penegak hukum, kurangnya pemahaman dan kesadaran masyarakat tentang hukum dan faktor psikologis. Sedangkan faktor eksternal adalah faktor yang berasal dari luar diri masyarakat. Faktor ini antara lain: faktor lemahnya penegakan hukum, substansi hukum, struktur hukum, dan budaya hukum.

\section{DAFTAR PUSTAKA}

\section{a. Buku}

Abdurrahman (1979). Aneka Masalah Hukum Dalam Pembangunan di Indonesia. Bandung: Alumni.

Ali, Zainudin (2008). Sosoilogi Hukum, Jakarta: Sinar Grafika.

Munir, Fuady (2007). Sosiologi Hukum Kontemporer, Interaksi Kekuasaan, Hukum, dan Masyarakat. Bandung: Citra Aditya Bakti. 
Muladi (1997). Hak Asasi Manusia Dan Sistem Peradilan Pidana. Semarang: Badan Penerbit Universitas Diponegoro.

Muladi dan Arief, Barda Nawawi (1984). Teori-Teori dan Kebijakan Pidana. Bandung: Alumni.

Chairuddin, OK. (1991). Sosiologi Hukum, Jakarta: Sinar Grafika.

Rahardjo, Satjipto (1983). Aneka Persoalan Hukum dan Masyarakat. Bandung: Alumni.

Sidharta, Bernard Arief (1999). Refleksi Tentang Struktur Hukum Sebuah Penelitian Tentang Kefilsafatan dan Sifat Keilmuan Hukum Sebagai Landasan Pengembangan Ilmu Hukum Nasional Indonesia. Bandung: Mandar Maju.

Sihombing, Justin (2005). Kekerasan Terhadap Masyarakat Marginal. Yogyakarta: Narasi.

Soekanto, Soerjono (1982). Kesadaran Hukum Dan Kepatuhan Hukum. Jakarta: Rajawali.

(1983). Beberapa Aspek Sosio Yuridis Masyarakat. Bandung: Alumni (1989). Suatu Tinjauan Sosiologi Hukum Terhadap Masalah Sosial. Bandung: Aditya Bakti. (1990). Polisi dan Lalu Lintas, Bandung: Mandar Maju. (2009). Hukum Dan Perilaku. Jakarta: Kompas.

Salman, Otje (1993). Beberapa Aspek Sosiologi Hukum. Bandung: Alumni.

\section{b. Jurnal}

Usman, Atang Hermawan (2014). Kesadaran Hukum Masyarakat Dan Pemerintah Sebagai Faktor Tegaknya Negara Hukum Di Indonesia. Jurnal Wawasan Yuridika, 30(1).

Fitriati (2012). Perbuatan Main Hakim Sendiri Dalam Kajian Kriminologis dan Sosiologis. Jurnal Masalah-Masalah Hukum, 41(2).

Hartanto, Wenda (2015). Kesadaran Hukum sebagai Aspek Dasar Politik Hukum Legislasi: Suatu Tinjauan Filsafat. Jurnal Rechtsvinding 4(3).

Kristianto, Kiki (2015). Perbuatan Eigen Righting (Main Hakim Sendiri) Dalam Perspektif Hukum Pidana. Jurnal Morality, 2(2).

Meliala, Adrianus (2001). Perilaku Kolektif Dan Tindakan Anarkis: Perspektif Kepolisian. Jurnal Kriminologi Indonesia, 1(3).

Nurcahyaningsih (2015). Tinjauan Kriminologi Terhadap Perbuatan Main Hakim Sendiri (Studi Kasus Di Kelurahan Kawatuna Kota Palu). Jurnal Legal Opinion, 3(2).

Rosana, Ellya. (2014). Kepatuhan Hukum Sebagai Wujud Kesadaran Hukum Masyarakat. Jurnal TAPIs, 10(1).

Subhan, Achmad, Ruben, dan Syarifuddin, Amir (2014). Kajian Yuridis Tentang Perbuatan Main Hakim Sendiri Terhadap Pelakukejahatan Begal Motor Menuruthukum Pidana Indonesia. Legalitas 6(2). 
Tagel, Dewa Putu (2013). Kesadaran Hukum Masyarakat Pengguna Jalan Di Kota Denpasar. Udayana Master Law Journal, 2(2).

Widayati, Lidya Suryani (2015). Tindakan Main Hakim Sendiri dalam Info Singkat Hukum (Kajian singkat Terhadap Isu Aktual dan Strategis). Vol. VII, Nomor/05/1/P3DI/Maret 2015, Pusat Pengkajian, Pengolahan Data dan Informasi Sekretariat Jenderal DPR RI, Jakarta, 2015, hlm. 2.

\section{c. Artikel}

Serikat Putra Jaya, Nyoman (2000). Aspek Hukum Pidana Terhadap Tindakan anarkis Dan Main Hakim Sendiri Dalam Masyarakat. Makalah seminar Regional dengan tema "Kecenderungan Tindakan Anarkis dan Min Hakim Sendiri dalam Masyarakat" yang diselenggarakan oleh Polisi Wilayah Pekalongan bekerjasama dengan Universitas Pancasakti Tegal, pada tanggal 22 Agustus 2000.

Supianto, Eli (2014). Tinjauan kriminologis terhadap tindakan main hakim sendiri (eigenrechting) yang dilakukan oleh massa terhadap pelaku tindak pidana (Studi Kasus di Kota Makassar Tahun 2009 s/d 2012). Skripsi, Fakultas Hukum Universitas Hasanuddin Makassar.

Suwarno, Abdul Syani, dan Pairulsyah, (2012). Analisis Prilaku Kekerasan Massa Dan Upaya Penanggulangannya (Studi Kasus Konflik Antar Etnis Di Kecamatan Sidomulyo Kabupaten Lampung Selatan). Seminar Hasil-Hasil Penelitian dan Pengabdian Kepada Masyarakat-Dies Natalis FISIP Unila Tahun 2012. 